\title{
IN SEARCH OF LEGAL FOUNDATION FOR INDONESIAN FAMILY FIRMS
}

\author{
Yetty Komalasari Dewi
}

* Department of Civil Law, Faculty of Law Universitas Indonesia

\author{
Article Info \\ Received : 7 April 2016| Received in revised form : 3 August 2016| Accepted : 16 August 2016 \\ Corresponding author's e-mail : yettykomalasaridewi@gmail.com
}

\begin{abstract}
One of the factors that affect Indonesia's economic growth is the existence of business firms. Most business firms in Indonesia are in the form of family-owned firm, and they are considered to constitute the backbone of the economic development. Family firms represent the most enduring business model in the world. The continuing success of family firms through the generations relies on ensuring the next generation. However, the issue of family firms is rarely discussed in particular from the perspective of corporate law. In fact, from legal perspectives, there are some issues dealing with this type of firm, among other, the lack of an overall definition of the term "family business". It is because family businesses and small medium enterprises (SMEs) are widely understood synonymously in spite of the fact that they exist in every size class. Other issue is the question of its legal basis or legal framework in terms of its corporate governance. Many Indonesian business players lack the basic understanding of corporate law. It is partly because obligations set out in the corporate law are incompatible with the values and cultures in Indonesia where "kinship principle" is deeply rooted. This article aims to describe the characteristics and the legal frameworks for family firms in Indonesia. It also recommends the government to take progressive measures by providing clear regulations on family firms in Indonesia. This will reinforce family firms' contribution to economic development of Indonesia in the future.
\end{abstract}

Keywords: family firms, family business, corporate law

\begin{abstract}
Abstrak
Salah satu faktor yang memengaruhi pertumbuhan ekonomi Indonesia adalah keberadaan dari badan usaha. Tidak dapat dipungkiri bahwa badan usaha di Indonesia merupakan usaha keluarga, yang menjadi tulang punggung utama dari pembangunan ekonomi nasional. Perusahaan keluarga memperlihatkan model bisnis yang paling bertahan di dunia. Kelanjutan keberhasilan dari perusahaan keluarga bergantung kepada penerusan kepada generasi selanjutnya. Akan tetapi, permasalahan mengenai perusahaan keluarga merupakan pembahasan yang jarang dibahas dalam perspektif hukum perusahaan. Faktanya, dari perspektif hukum, terdapat beberapa permasalahan dalam bentuk usaha semacam ini, antara lain yaitu kurangnya definisi mengenai istilah "usaha keluarga" itu sendiri. Hal ini karena perusahaan keluarga dan usaha kecil dan menengah (UKM) dipahami sebagai hal yang sama, meskipun pada kenyataannya perusahaan keluarga terdapat berbagai jenis dan ukuran, tidak hanya UKM. Permasalahan lainnya adalah mengenai dasar hukum atau kerangka hukum dari aspek tata kelola perusahaan. Banyak pelaku usaha Indonesia kurang memahami pemahaman mendasar tentang hukum perusahaan. Hal ini sebagian karena kewajiban-kewajiban tata kelola perusahaan tersebut bertentangan dengan nilai dan budaya di Indonesia di mana prinsip kekeluargaan tertanam dalam. Tulisan ini bertujuan untuk menggambarkan karakteristik dan kerangka hukum untuk usaha keluarga di Indonesia. Tulisan ini juga memberikan rekomendasi kepada Pemerintah untuk mengambil kebijakan progresif dengan memberikan peraturan hukum yang jelas untuk perusahaan keluarga di Indonesia. Hal ini akan menguatkan peranan perusahaan keluarga kepada pembangunan ekonomi Indonseia di masa depan.
\end{abstract}

Kata kunci: hukum perusahaan, perusahaan keluarga, usaha keluarga. 


\section{Introduction}

Family ${ }^{1}$ firms are one of the foundations of the world's business community. They form the basic building block for business throughout the world. Their creation, growth and longevity are critical to the success of the global economy. The economic and social importance of family business ${ }^{2}$ has now become more widely recognized. The proportion of family firms is estimated to range from $75 \%$ in the UK, more than $95 \%$ in India, ${ }^{3}$ and about $90 \%$ in Indonesia (out of 160 thousand companies). ${ }^{4}$

This increasing interest in family firms is due to economic reasons and social reasons. With reference to the economic reasons, a large part of the business in Indonesia is family firms. They provide a substantial part of Indonesian employment opportunities. With reference to the social reasons, family firms also play an important role in the community. Family firms often have a special place in the region and are actively involved in the community and are strongly involved with their employees.

In the Netherlands, for example, around $80 \%$ of the companies with ten or more employees can be defined as a family firm or Vereniging Familiebedrijven Nederlands, and these companies account for $50 \%$ of the employment. ${ }^{5}$ In addition, about $50 \%$ of the gross domestic product is derived from family firms and that around $15 \%$ of the 100 biggest companies in the Netherlands can be defined as family business. ${ }^{6}$ In Indonesia, $82.44 \%$ of the gross domestic product is derived from family firms. ${ }^{7}$ In 2014, PwC Survey stated that in Indonesia 83\% of family firms grew in the last financial year, compared with $65 \%$ globally. ${ }^{8}$

Studies have confirmed that family firms is the most common form of business structure because family firms employ many millions of people and they generate a considerable amount of the world's wealth. Unfortunately, very few attempts have been made to evaluate the existence and the contribution of family businesses worldwide. The similar situation occurs in Indonesia as well.

This article aims to describe the characteristics and the legal frameworks for family firms in Indonesia. The discussion begins with an elaboration of what defines firms as family firms and its characteristics from international perspectives. The next section discusses the definition, legal foundation, policy framework and challenges of the Indonesian family firms. The last section provides some recommendations to be taken by policy makers in order to create a more conducive environment for

${ }^{1}$ For this purpose, family defined is as persons knowingly related by blood or marriage.

2 The terms family firm, family corporation, family-held company, or more loosely, family business, are coterminous and are used interchangeably. However because it is more neutral than others, the phrase "family firms" will be the primary usage in this article.

3 Sir Adrian Cadbury, Family Firms and their Governance: Creating Tomorrow's Company form Today's (Great Britain: Egon Zehnder International, 2000), p. 5

${ }^{4}$ SWAOnline, “Ketika Perusahaan Keluarga Berhadapan 'Seven-plus-Seven',' [“When Family Companies facing 'Seven-plus-seven'”], http://swa.co.id/business-strategy/ketika-perusahaan-keluarga-berhadapanseven-plus-seven, accessed on March 2013. See also: “Family Business Contribute to Nation's GDP," http:// www.uii.ac.id/content/view/2116/257/, accessed on 26 March 2013.

${ }^{5}$ Martin Koopman and Kevin Sebel, The Internationalization of Family Firms: Facilitating and Contraining Features, (Jonkoping International Business School, 2009), p. 2.

${ }^{6}$ Ibid.

${ }^{7}$ Swara Karya, June 28, 2007.

${ }^{8}$ PricewaterhouseCoopers, "PwC Survey: Family businesses in Indonesia grow stronger and see professionalising the business as key concern,"http://www.pwc.com/id/en/media-centre/press-release/2014/ english/family-business-survey-indonesia.html, accessed on May 20, 2015. 
Indonesian family firms.

\section{Understanding "Family Firm" and Its Characteristics}

\section{A. Defining Family Firm}

This section explains an overview of how family business is defined by scholars in the different countries, particularly in Indonesia. To start with, there is no general definition of what a family firm is. In the $19^{\text {th }}$ century and in $20^{\text {th }}$ century, economic activity was so heavily dominated by family firms that there was no need to give it a specific name to distinguish it from other legal and organizational forms. It is no surprise, therefore, that there is no general consensus among scholars as to what constitutes a family firm. ${ }^{9}$

Special literature clearly shows that

there is not a single definition of 'family business' that exclusively applies to every conceivable area, such as to public and policy discussion, to legal regulations, as an eligibility criterion for support services, and to the provision of statistical data and academic research. ${ }^{10}$

Below are definitions provided by experts or scholars dealing with this type of firm:

\section{Anderson \& Reeb}

They define family firm as the fractional equity ownership of the founding family and (or) the presence of founding family members on the board of directors. ${ }^{11}$ Therefore, a corporation qualifies as a "family firm" if the founding families hold shares in the firms or a founding family member is on the board of directors.

2. Akira Suehiro

He provides the broadest sense of the term that a business formed through an affiliation such as a family, a personal relationship, or a common place of origin may be defined as a family business. In his opinion, family business is a form of enterprise in which both the ownership and management are controlled by a family kinship group, either nuclear or extended, and the fruits of which remain inside that group, being distributed in some way among its members. ${ }^{12}$

3. Miller,et. al.

According to them, a family firm is a firm in which multiple members of the same family are involved as major owners or managers, either contemporaneously or over time. ${ }^{13}$

4. Lefort

\footnotetext{
${ }^{9}$ H. Littunen and K. Hyrsky, "The Early Entrepreneurial Stage in Finnish Family and Non Family Firms," Family Business Review13, no. 1 (2000), pp. 41-54.

${ }^{10}$ KMU Forschung Austria, “Overview of Family Business Relevant Issues”, (KMU Forschung Austria: Vienna, 2008), p. 1.

11 Anderson and Reeb, "Founding-Family Ownership and Firm Performance: Evidence from the S7P 500," The Journal of Finance 58,3 (June 2003),p. 1308.

12 Akira Suehiro, "Family Business Reassessed: Corporate Structure and Late-starting Industrialization in Thailand," The Developing Economies 31, no. 4(December 1993), pp. 378-407.

13 Miller,et. al., "Are Family Firms Really Superior Performers?" Journal of Corporate Finance13, no. 5(December 2007), p. 829.
} 
He defines a family business as a company in which a majority of shares are held directly or indirectly by members of a family or clan and, more importantly, a company whose manager(s) are also members of that family. ${ }^{14}$

5. Sir Cadbury

By his definition, family firm is all enterprises that are owned, managed or significantly influenced by a family or families. ${ }^{15}$ It means that the family has the final say in whoever is responsible for managing the firm.

6. PricewaterhouseCoopers.

In one of its surveys, it defines family business as companies in which at least $52 \%$ of the shares are held by a family or related families, the family members comprise the majority of the senior management team and the owners have dayto-day responsibilities for the management of the business. ${ }^{16}$

7. European Group of Owner Managed and Family Enterprises

The group defines a firm as a family business if meet the criteria: (1). The majority of ownership (directly or indirectly) rests in the hands of a natural person/and of family; and (2). At least one representative of the family or kin is involved in the management or administration of the firm. ${ }^{17}$

8. Astrachan, Klein \& Smyrnios

They state that an enterprise can be viewed only as a family business when a transfer to the next generation is intended; others consider at least one generational transfer should have occurred. ${ }^{18}$

9. Chua,et. al.

In their opinion, the family business is a business governed and/or managed with the intention to shape and pursue the vision of the business held by a dominant coalition controlled by members of the same family or a small number of families in a manner that is potentially sustainable across generations of the family or families. $^{19}$

Based on the above definitions, it is essential to agree on an accepted definition of what a family business is to have a better view. A narrower definition views that a business is a family business if at least the second generation is involved in the company and a majority of the management consists of family members. ${ }^{20} \mathrm{~A}$ broad

${ }^{14}$ Fernando Lefort, “Ownership Structure and Market Valuation of Family Groups in Chile," Corporate Ownership \& Control 3, no. 2 (2005-2006), pp. 90\&92.

${ }^{15}$ Cadbury, loc.cit.

${ }^{16}$ PricewaterhouseCoopers, Making a Difference, The PricewaterhouseCoopers Family Business Survey 2007/08, https://www.pwc.co.za/en/assets/pdf/pwc-family-business-survey-08.pdf, accessed 10 January 2013.

17 European Commission Enterprise and Industry Directorate-General, "Final Report of the Expert Group on Overview of Family-Business-Relevant Issues: Research, Networks, Policy Measures, and Existing Studies", http://ec.europa.eu/enterprise/policies/sme/promoting-enterpreneurship/family-business, accessed on 27 March 2013. See also: Roberto Floren, Lorranine Uhlaner and Martha Berent-Braun, "Family Business in the Netherlands, Characteristics and Success Factors," A Report for the Ministry of Economic Affairs,Center for Entrepreneurship, Nyenrode Business Universiteit, Breukelen, the Netherlands, January 25 (2010).

${ }^{18}$ Joseph H. Astrachan, Sabine B. Klein and Kosmas X. Smyrnios, “The F-PEC Scale of Family Influence: A Proposal for Solving the Family Business Definition Problem,"Family Business Review15, no. 1 (2002), p. 49.

${ }^{19}$ Jess H. Chua, James J. Chrisman and Pramodita Sharma, "Defining the Family Business by Behavior," Entrepreneurship Theory and Practice (Summer 1999):p. 25.

20 R.H. Floren, "Facts and Figures of the Family Business: 10 years of research on family business," 
general definition of family firm is one where a family owns enough of the equity to be able to exert control over strategy and is involved in top management positions. ${ }^{21}$ This definition is one of the most used definitions today and can also be considered a useful benchmark.

We can conclude that the types of business organizations or companies appear irrelevant in these definitions. Thus, any types of business organizations or companies could be regarded as "family firms" insofar as they have intimate relationship such as blood or marriage.

Although there are many definitions of family business, there is a general agreement that a definition of family business has to incorporate three essential elements: family, business and ownership.

By far the most pervasive form of corporate ownership and control worldwide is by wealthy families and individuals. This is the trend in a significant majority of countries, predominantly the countries of Latin America, continental Europe, South and East Asia, and Africa. ${ }^{22}$ Studies have confirmed the prevalence of concentrated family ownership in continental Europe ${ }^{23}$ and East Asia. ${ }^{24}$ In most countries, the national economy literally rested in the hands of few family owners, such as in Indonesia and the Philippines, $16.6 \%$ and $17.1 \%$ respectively of the total value of listed corporate assets were traceable to the ultimate control of a single family. ${ }^{25}$ In the Philippines, Thailand and Indonesia the largest ten families controlled half of the corporate assets. ${ }^{26}$

Family firm is not only the most pervasive business unit worldwide, particularly in developing countries, but also family owners tend to play active roles in its management. ${ }^{27}$ Founders and their heirs play active roles in the management of family firms either by sitting on the board or actively directing the corporation's affairs. Family control is, therefore, higher among mid-sized corporations as $80 \%$ or more of companies in Indonesia, Korea, Malaysia and Taiwan have managers who belong to the controlling group..$^{28}$

Why are there more family firms in developing countries? Family firms dominate developing countries for a very simple reason that they are "developing countries". It is clear that in all countries the first large corporations were family businesses and that in countries with short industrial histories family firms still dominate. ${ }^{29}$ Historically,

www.nyenrode.nl, accessed 10 January 2013.

${ }^{21}$ Andrea Colli and Mary Rose, "Family Business," in The Oxford Handbook of Business and History, edited by Geoffrey G. Jones and Jonathan Zietlin (Oxford: Oxford University Press, 2008), p. 194.

${ }^{22}$ Mike Burkart, Fausto Panunzi \& Andrei Schleifer, “Family Firms,"Journal of Finance 58, no. 5 (2003): p. 2167.

${ }^{23}$ Mara Faccio and Larry H. P. Lang, “The Ultimate Ownership of Western European Corporations,"Journal of Financial Economics Volume 65 Issue 3 (September 2002): p. 365.

${ }^{24}$ Stijn Claessens, Simeon Djankov and Larry H.P.Lang, "The Separation of Ownership and Control in East Asia Corporations," Journal of Financial Economics 58, issue 1-2 (2000): p. 103.

${ }^{25}$ Ibid.

${ }^{26}$ Ibid.

27 Faccio and Langstated that more than two-thirds of the family-controlled firms have top managers from the controlling family.Faccio and Lang, op.cit.,p. 357

${ }^{28}$ Claessens, Djankov and Lang, op.cit., p. 94

${ }^{29}$ Randall K. Morck \& Lloyd Steier, "The Global History of Corporate Governance: An Introduction," in A History of Corporate Governance Around the World, edited by Randall K. Morck (Chicago: University of Chicago Press 2005), p.8. They stated that: "Mom-and-pop stores in India, Italy and the United States all tend to be owned by mom and pop". 
in the early stages of industrialization, family firm was appropriate in terms of scale and structure to the size and structure of markets, to contemporary technology, to the level of capital resources required, and to the feasibility of workforce control and supervision. ${ }^{30}$ With family firms, kinship ties offset the uncertainties and risks associated with very imperfect information flows that characterize those early years of industrialization. ${ }^{31}$

From an anthropological perspective, family is considered as the original economic unit. ${ }^{32}$ By this characterization, family provides the needs of its members, and they in turn contribute to its sustenance. Since large businesses typically start on a smaller scale, most small-scale business organizations are owned directly by individuals and families and, if they survive collapse, devolve on heirs and other relations of the founder. Several of such firms can spawn across the length and breadth of a country and in countries yet to develop strong markets, such business units can become very important players in the national economy. ${ }^{33}$

\section{B. Distinctiveness/Characteristics of "Family Firms"}

The most distinctive characteristic of a family business is the family itself. The common feature of these companies is that of the family dimension, where business and ownership are intertwined. A family can influence a business via the extent of its ownership, governance, and management involvement. The family involvement in ownership and management makes them different from other types of firms. However, the presence of the family in the ownership and management can be a benefit or a disadvantage for a family firm's competitiveness. Family influence through governance and management can be measured as the proportion of family representatives who are members of the governance or management boards.

The essence of a family business consists of a vision developed by a dominant coalition controlled by one or a few families and the intention of that dominant coalition to continue shaping and pursuing the vision in such a way that it is potentially sustainable across generations of the family.

The value-based management is an area in which family firms have excelled for years. ${ }^{34}$ The family's value system is often aligned with the value system in the business. Corporate values at the foundation of family firms' culture are different from those encountered in non-family firms. The corporate values in family-owned firms tend to be more oriented toward people, as opposed to focusing exclusively on financial profits. ${ }^{35}$

The governance of a family firm is more complex than the governance of a firm with no family involvement. Family relationships have to be managed in addition to

${ }^{30}$ Roy Church, "The Family Firm in Industrial Capitalism: International Perspectives on Hypotheses and History,"Business History 35, no. 4 (1993): p. 19.

${ }^{31}$ Ibid.

32 William S Schulze and Eric Gedajlovic (2010), "Whither Family Business,"Journal of Management Studies47, no. 2 (March 2010):p. 192.

${ }^{33}$ Burton Benedict, "Family Firms and Economic Development,"Southwestern Journal of Anthropology 24, no. 1 (Spring, 1968):p. 1.

${ }^{34}$ J.L.Ward, "Introduction," in Family values and values creation. The fostering of enduring values within family-owned businesses, edited by J. Tapies and J.L. Ward (Hampshire, England: Palgrave Macmillan, 2008), pp. 1-8.

${ }^{35}$ Lucia Ceja \& Josep Tapies, “Corporate Values Guiding the World’s Largerst Family-Owned Business: A Comparison with Non-Family Firms,"Working Paper-916 (IESE Business School, University of Navarra, 2011). 
business relationship.

Thus, the notion of ownership is fundamental to family business. It enables a clear distinction to be made between family and non-family business. Taking the 'ownership perspective' rather than the 'company size' perspective can help improve understanding of this phenomenon.

When comparing family business with non-family business, there are several differences described as follows: ${ }^{36}$

\section{Table 1: Comparison between Family Business and Non-Family Business}

\begin{tabular}{ll}
\hline \multicolumn{1}{c}{ Family Business } & \multicolumn{1}{c}{ Non-Family Business } \\
\hline The purpose is continuity & The purpose is maximizing near-term share price \\
\hline $\begin{array}{l}\text { The goal is to preserve the assets and } \\
\text { reputation of the firm }\end{array}$ & $\begin{array}{l}\text { The goal is to meet institutional investors' } \\
\text { expectations }\end{array}$ \\
\hline $\begin{array}{l}\text { The fundamental belief is that the first priority } \\
\text { is to protect against downside risk }\end{array}$ & $\begin{array}{l}\text { The fundamental belief is that more risk promises } \\
\text { more return }\end{array}$ \\
\hline The strategic orientation is adaptation & The strategic orientation is constant growth \\
\hline $\begin{array}{l}\text { The most important stakeholders are } \\
\text { customers and employees }\end{array}$ & $\begin{array}{l}\text { The most important stakeholders are shareholders } \\
\text { and management }\end{array}$ \\
\hline $\begin{array}{l}\text { The management's focus is continuous } \\
\text { incremental improvement }\end{array}$ & The management's focus is innovation \\
\hline The business is seen as a social institution & The business is seen as a disposable asset \\
\hline Leadership is stewardship & Leadership is personal charisma \\
\hline
\end{tabular}

Based on the above differences, it appears that the family firm is more people oriented.

\section{Strengths and Weaknesses of Family Firms}

Family firms have several strengths as follows:

a. Involvement. Families in a family business can be very attached to the company and its employees. Family commitment to building up a profitable enterprise gives a family firm its competitive edge. When the enterprise starts, the family has a single goal to which all its members can subscribe. The enthusiasm of the family also creates involvement andloyalty with their employees who might feel that they are part of the team. ${ }^{37}$

b. Knowledge. The founder of a business is a major source of knowledge and expertise and his or her social networks represent important intangible assets for the company. Knowledge generated within the company may be protected by the family. Loyalty and commitment to family members is assumed to lead to altruism by parents towards their offspring. ${ }^{38}$ The future prosperity of both family

${ }^{36}$ A. J. Thomassen, "Family Business in the Netherlands: Historical Perspective and Future Issues" (presentation for European Commission, DG Enterprise and Industry, May 24, 2007); based on KMU Forschung Austria, Overview of Family Business Relevant Issues, Final Report No. 30-CE-0164021/00-51, http://ec.europa.eu/DocsRoom/documents/10389/attachments/1/translations/en/renditions/native, accessed 10 March 2013, p. 10.

37 Leach P, The Story Hayward Guide to the Family Business, Story Hayward, $1^{\text {st }}$ ed. (The Mark Press Limited: London, 1991).

${ }^{38}$ James H. S. Jr. "Owner as Manager: Extended Horizons and the Family Firm," International Journal of Economy and Business6 (1999): pp. 41-56. 
and business depend upon how well understanding and contacts are passed on and how far these are trusted and valued by the next generation. ${ }^{39}$ In other commercial companies knowledge generated within the company may sooner become common knowledge.

c. Long term vision. Family firms see the family interest as a continuing one and tend to take the long-term view in coming to decisions. It is the sense of building a business for future generations that underlies the policies of successful family firms. ${ }^{40}$

d. Rapid decision-making. The responsibilities within a family are usually centered with one or two key figures. Since the family both owns and manages the firm, decision-making is straightforward, because the interests of the owners and the managers do not have to be considered separately; the firm can run with minimum overheads drawing on the family's own resources. ${ }^{41}$

e. Business culture. Business culture is an important element of family enterprise. A firm can be considered a family business when family and business share assumptions and values. ${ }^{42}$

f. Clear identity. Family firms have also a clear identity because they are built on a human scale and the people who work in the firm know for whom they are working. Therefore, family firms generally have the loyalty of the entire families of employees and there is often a continuing family tradition of working in them. ${ }^{43}$

Apart from their strengths, family firms face some weaknesses, i.e. limited career growth opportunities for non-family members and conflicts within the family as the wife of the family CEO can influence the business in a substantial way. It is stated that CEO spouses play a key, even if often invisible, role in most family-controlled corporations; ${ }^{44}$ there is rigidity as family business may tend to continue doing things in the same way and do not change anything; and succession as transfer of the family business from one generation to another may be difficult. There has to be a transfer in leadership and in property and in the case of obtaining capital the directors of the company may have difficulties with the idea of obtaining capital from a third party.

\section{III.Challenges of Family Firms}

Family firms tend to blur work and family. This problem arises from seeing the business and the family life as one, as a unity. There is no separation between family relationship and business relationship. In order to continue growth, a family firm will have to draw in managers from outside the family. This will require the management of the relationship between family and non-family members of the firm. The sharing of power, which the acceptance of non-family managers requires, is one of the hardest issues for family firms to come to terms with. ${ }^{45}$

Many of the challenges faced by family businesses also concern SMEs in general.

39 D.S. Lim Lee and W.S. Lim, "Family Business Succession: Appropriation Risk and Choice of Successor," Academy of Management Review 28, no. 4 (October 2003): pp. 657-666.

${ }^{40}$ Cadbury, op.cit., p. 6.

${ }^{41}$ Ibid.

42 E.J. Poza and T. Messer, "Spousal Leadership and Continuity in the Family Firm," Family Business Review14, no. 1 (March 2001):pp. 25-36.

${ }^{43}$ Cadbury, loc.cit., p. 7

${ }^{44}$ Poza and Messer, loc.cit.

${ }^{45}$ Cadbury, op.cit., p. 8. 
Some challenges stem from the environment in which companies operate, e.g. policy makers are unaware of the specificities of family businesses and their economic and social contribution; financial issues related to gift and inheritance tax, access to finance without losing control of the firm, and favorable tax treatment of reinvested profits. Some are related to the family firm's internal matters e.g. unawareness of the importance of planning company transfers early and balancing the family, ownership and business aspects within the enterprise.

The challenges can be divided into two categories: challenges that arise from the business environment and challenges that arise from the family firm's internal matters.

\section{A. Challenges that arise from the business environment}

Challenges that arise from the business environment, i.e. unawareness of policy makers of the specificities of family business, and their economic and social contributions; and financial issues (e.g. gift and inheritance tax, access to finance without losing control of the firm, favorable tax treatment of reinvested profits):

1. Unawareness of policy makers of the specificities of family business, and their economic and social contributions.

This unawareness is caused by the traditionally discrete behavior of the sector. There is still a lack of robust data that usually leads to inaccurate assumptions such as equating all family business with SMEs. The availability of reliable information is essential to make policy makers aware of the importance of the family business sector. It is important as well to have a clear and precise picture of the real contribution that family businesses make to society.

2. Financial issues.

Family businesses face the same financial constraints as any other type of business. The payment of inheritance and/or gift represents the biggest challenge. Tax systems are typically set up to counteract wealth accumulation and as a result may put financial pressure on the family company, which can destabilize its capital base.

\section{B. Challenges that arise from the family firm's internal matters}

Challenges that arise from the family firm's internal matters, i.e. unawareness by family firms of the importance of planning business transfers early and balance among the family, ownership and business aspects within the enterprises.

\section{Family Firms in Indonesia}

\section{Contribution}

In Indonesia, the presence of family firms cannot be ignored since family business can be small, medium-sized or large companies and listed or unlisted companies. Indonesian Central Bureau of Statistics (BPS) states that family business in Indonesia is private company contributed up to $82.44 \%$ of Indonesian gross domestic product. ${ }^{46}$ In 2012, Forbes estimated the total wealth of 40 richest people in Indonesia reached USD 88.6 billion. Of the 10 richest persons in Indonesia, most of them are family

\footnotetext{
${ }^{46}$ Swara Karya, June 28, 2007.
} 
firms ${ }^{47}$ In addition, about $5 \%$ of family firms in Indonesia, which last up to four generations (G4), have contributed to the national economy. ${ }^{48}$ A survey shows a trend that continues to decline in the second generation with only $61 \%$, only $24 \%$ in third generation, and only $5 \%$ in the next generation. Some family firms survive to the next generation, among others, Kalla Group, Kalbe Farma, Mustika Ratu, Bosowa Group, Samudera Indonesia, Sinar Mas, Nyonya Meneer, Danarhadi and others. ${ }^{49}$

Most family firms start out as family firms with a high degree of family involvement and an expectation of trans-generational succession. ${ }^{50}$ There are some interesting findings regarding decision-making patterns in Indonesian family businesses. ${ }^{51}$ The concept of collectivism in making decisions and strategic policies is strongly maintained by $74 \%$ of family businesses in Indonesia. ${ }^{52}$

For example, Salim Group is a family business group from Indonesia. The Salim Group was founded by Sudono Salim (Liem Sioe Liong) and grew to be the largest diversified business group in Southeast Asia. The turnover in 1994 of its 450 companies was believed to be greater than that of any other business groups in Southeast Asia, Taiwan, or Hong Kong. ${ }^{53}$ Salim Group alone accounts for $5 \%$ of Indonesia's Gross Domestic Product. ${ }^{54}$ Salim group focused on a consistent local-forlocal business model, has undergone substantial changes in its business networks by not merely focused on ethnic and political connection as in the early days, but by making more exposure to foreign partners. ${ }^{55}$ The transition to the second-generation leadership marked a shift to a new corporate strategy.

\section{Definition and Policy/Legal Framework}

Definition. Most Indonesia businesses are family owned, and yet the law governing businessorganizations does not adequately account for family relationships. Nor have legal scholars paid sufficient attention to family businesses. There is no precise definition of family firm, much less its legal definition. There are also no regulations referring to family firm nor specific legal frameworks for family firm. However, a family firm may still, legally speaking, take a form of partnership ("Persekutuan") ${ }^{56}$ or

${ }^{47}$ The list of the top 10 conglomerates in Indonesia according to Forbes release in 2015 are: Hartono Family, USD 15.4 billion (PT Djarum); Susilo Wonowidjojo \& Family, USD 5.5 billion (tobacco); Anthoni Salim \& Family, USD 5.4 billion (diversified); Eka Widjaja Tjipta \& Family, USD 5.3 billion (palm oil); Chairul Tanjung, USD 4.8 billion (diversified); Sri Prakash Lohia, USD 4.7 billion (polyester); Bachtiar Karim, USD 3.3 billion (manufacturing); Boenjamin Setiawan \& Family, USD 3 billion (pharmaceuticals); Mochtar Riady, USD 2.2 billion (diversified); Tahir, USD 2 billion (diversified). Source: Forbes, http://www.forbes. com/indonesia-billionaires, accessed on 15 February 2015.

${ }^{48}$ AB Susanto, "Menguak Perusahaan Keluarga di Indonesia," ["Revealing Family Firms in Indonesia”] http://www.jakartaconsulting.com/art-0507.htm, accessed 26 March 2013.

${ }^{49}$ Ibid.

${ }^{50}$ Jess H. Chua, James J. Chrisman and Erick P.C.Chang, "Are Family Firms Born \& Made? An Exploratory Investigation," Family Business Review17, no.1 (2004): pp. 37-54.

${ }^{51}$ Susanto, loc.cit.

52 “Leadership in Family Business,"http://www.thepresidentpost.com/?p=15411, accessed February 2013.

53 John Bresnan, et.al., Indonesia: The Great Transition (Weatherhead East Asian Institute Columbia University: Rowman \& Liitlefield Publishers, 2005), p. 221.

54 Murray Weidenbaum, "The Chines Family Business Enterprise,"California Management Review 38, no. 4(1996): p. 142.

55 Marleen Dieleman, How Chinese are Entrepreneurial Strategies of Ethnic Chinese Business Groups in Southeast Asia? A Multifaceted Analysis of the Salim Group of Indonesia (Netherlands: Leiden University Press, 2007), pp. 11-12.

56 Commercial Partnership may be divided into two types: General Partnership (or Firma, abbrevi- 
Indonesian limited liability company ("Perseroan Terbatas", commonly abbreviated as "PT") or corporation. ${ }^{57}$

Currently, firms or business enterprises in Indonesia are governed by several acts depending on the types or forms of the enterprises. The limited liability company or corporation is governed by Law No. 40 of 2007. Other types of business firms, such as limited partnership (Commanditaire Vennootschap) and general partnership (Vennootschap onder Firma), and civil partnership (Maatschap) are governed by the Wetboek van Koophandel voor Indonesie or known as the Indonesian Commercial Code and the Burgerlijk Wetboek voor Indonesie or known as the Indonesian Civil Code; ${ }^{58}$ Cooperatives is governed by Law No. 17 of 2012 regarding Cooperatives.

Family firms in the form of a limited liability company shall be governed by Law No. 40 of 2007 regarding Limited Liability Companies. It means that any person having blood or marriage relationship is eligible to be the incorporator of a PT, a member of the Board of Directors or a member of the Supervisory Board and they must adhere to the company's articles of association, the Law and its implementing regulations. Whereas family firms in the form of non limited liability company shall be governed by Indonesian Commercial Code, Civil Code and/or other relevant regulations.

The SMEs are governed by Law No. 20 of 2008 regarding Micro, Small, and Medium Enterprises and its implementing regulations, namely Government Regulation No. 17 of 2013.

Policy/Legal Framework. There is no policy or legal framework for family firm. The policy framework is focused on entrepreneurship and small-medium enterprises (SMEs) and in general is aimed at all enterprises. The policy is aimed at a large number of fields such as improving the access to financing, the reduction of administrative burdens and simplification of regulations. Although the policy is general, special attention is paid to the stimulation of start-ups and theheir development of growth. There are no measures specifically aimed at family business, but as the policy is aimed at all enterprises, the policy also affects family businesses.

It should be understood that family firms are not the same as SMEs. Law No. 20 of 2008 concerning Micro, Small, and Medium Enterprises, defines: ${ }^{59}$

a. micro enterprises/businesses as enterprises with net assets less than $R p 50$ millions (land and building excluded) or; enterprises which have less than Rp 300 millions total annual sales.

b. small enterprises/businesses are as enterprises with net assets from $\mathrm{Rp} 50$ millions - Rp 500 millions (land and building excluded) or; enterprises with total annual sales from $R p 300$ millions - Rp 2.5 billions.

c. Medium enterprises/businesses as enterprises with net assets from $R p 500$ millions - Rp 10 billions (land and building excluded) or; enterprises with total annual sales from $R p 2.5$ billions - Rp 50 billions.

ated from Vennotschap onder Firma) and Limited Partnership (or CV, abbreviated from Commanditaire Vennotschap). See Wetboek van Koophandel voor Indonesie (Indonesian Commercial Code), Staatblad. 1847-23 (Law Gazette 1847-23), Art. 16 and 19.

${ }^{57}$ Indonesia, Undang-Undang tentang Perseroan Terbatas (Law on Limited Liability Companies), UU No. 40 Tahun 2007, LN No. 106 Tahun 2007 (Law No. 40 of 2007, SG No. 106 of 2007).

${ }^{58}$ Burgerlijke Wetboek (Indonesian Civil Code), Staatblad. 1847-23 (Law Gazette 1847-23), Article 1618 - 1652, and Wetboek van Koophandel voor Indonesie (Indonesian Commercial Code), Article 16-15.

${ }^{59}$ Indonesia, Undang-undang tentang Usaha Mikro, Kecil, dan Menengah (Law regarding Micro, Small, Medium Enterprises), UU No. 20 tahun 2008, LN No. 93 tahun 2008 (Law No. 20 of 2008, SG No. 93 of 2008), Article 16. 
Based on this definition, it is clear that the government takes the "size" rather than the "ownership" approach in classifying or categorizing "enterprises". Therefore, it is not easy to have accurate information or data regarding family firms. For example, enterprises that can be classified as "micro enterprise" may take the legal form of Firma, CV or PT. The government does not make a distinction between family firms and non-family firms; since the only differentiating factor is whether a firm is considered as small (micro), medium, or large. Thus, "enterprises" under this definition may take the legal form of Firma, CV, PT or even sole proprietorship.

On the other hand, the Ministry of Cooperatives \& SMEs of the Republic of Indonesia also divides enterprises/firms into three (3) categories. The first level is when the founders of the business do not have sufficient business knowledge and skills, for instance street vendors. ${ }^{60}$ The second level is when the founders of the businesses have some business knowledge but do not have the skills or vice versa. In this condition, they need other people to help them running their businesses. This kind of business might provide job opportunities. The third level is when the founders of the businesses have both the knowledge and the skills required to run business. This kind of businesses should be able to develop into multinational companies (MNC).

For medium-scale enterprises, the Ministry of Cooperatives \& SMEs provides an incentive or a facility in the form of direct capital for those who interested to opening a certain business.In order to obtain such facility, they have to submit their business plan proposal to be approved by the Ministry of SMEs. Based on this, it can be concluded that the government does not provide specific incentives for family firms, but for any firms/businesses. Perhaps it is because there is a perception that SMEs are family-owned businesses, which is not accurately true.

The policy regime on tax affirms that there is no certain tax treatment applying to family firms. ${ }^{61}$ The only distinction for companies or firms taxation is whether the company or firm is a legal person or a natural person. In other words, there are no tax incentives for family firms in Indonesia. However, there are certain tax incentives apply to small and medium enterprises (SMEs), if the family firms fall within the definition of SMEs.

\section{Challenges}

Decision making within family firms and their potential for growth is shaped partly by a formal and informal set of rules. The formal rules are the legal system including property rights, company law, taxation, inheritance tax, and bankruptcy law. The informal rules are formed by interaction between governments and business and other interested parties.

The legal status of particular types of company is a significant factor in explaining differences in the form family businesses may take. In Germany, for instance, corporate law encourages sustained family involvement in the businesses they founded, even after they went public. ${ }^{62}$ Inheritance law and company law change through time and this in turn influences family firms' strategy. In Indonesia, it is difficult to change inheritance law but it is not impossible to change company law to accommodate family firms' strategy.

\footnotetext{
${ }^{60}$ Interview with the 1 st Deputy of Institutional Cooperatives \& SMEs

${ }^{61}$ Interview with Head of Tax Billing, Inspection and Investigation for Lampung \& Bengkulu Regional Office, Directorate General of Tax, the Ministry of Finance of the Republic of Indonesia.

${ }^{62}$ Colli and Rose, op.cit, p. 202.
} 
As explained in the previous chapter that one of the challenges in family firms is to encourage them to become public companies. The same situation also applies in Indonesia. Family firms are hesitant about becoming public companies because they do not wish to improve their governance and management practices, as this will reduce the family's ability to enjoy private benefits of control. In other words, family firms are generally reluctant to become public as they do not want their shares owned by the public. The Chairman of the Capital Market Supervisory Agency and Financial Institution (Bapepam- $L K$ ) once stated that family businesses in Indonesia used to look for new capital through the bank and will conduct an IPO if they no longer bankable. ${ }^{63}$ To encourage family firms to do the IPO, Bapepam-LK will revise few regulations regarding tax incentives and reduce costs in doing the IPO ${ }^{64}$ The same opinion also posed by Governor of Bank Indonesia, Darmin Nasution in 2012. He said that most companies in Indonesia are a family company and they do not want to become a publicly traded company. He explained further that this private company should be encouraged to conduct an IPO. In order to do so, the government has made a variety of rules and incentives, such as tax incentives. If at company is willing to reduce its shares up 40 percent, it will obtain 5 percent of an income tax ${ }^{65}$

Having reviewed the existing rules on firms in Indonesia and even though Government has acknowledged the importance and specific characteristics of family firm, it is clear that to date there is no specific rule governing family firm which has been developed.$^{66}$ In the meantime, it is important to promote the exchange of best practices and utilize the expertise of national family business association to continue assist family business in running their companies for the long term.

\section{Conclusion}

Family firms have been a crucial feature of the business landscape for centuries and remain important today. Family firms are important, not only because they make an essential contribution to the economy, but also because of the long-term stability they bring, the specific commitment they show to local communities, the responsibilities they feel as owners and the values they stand for. It is important to understand that:

family business must be seen not only in terms of assets but as a combination of property and values. That is, family businesses have implications that involve more that merely serving a financial purpose; they are a means of sharing certain values and providing a service to the community in which they are integrated.$^{67}$

There is no specific legal foundation for family firms in Indonesia as it develops with the development of the society itself. Family firms exist in all forms of business organizations be it sole proprietorship, general partnership (Firma), limited

${ }^{63}$ Fuad Rahmany, Chairman of the Capital Market Supervisory Agency and Financial Institution (Bapepam-LK), http://finance.detik.com/read/2007/01/11/160347/729330/6/bapepam-dorong-perusahaan-keluarga-go-public, accessed on 15 May 2011. Up to now, the situation remains the same.

${ }^{64}$ Ibid.

65 Darmin Nasution, “Financial Lecture,"http://bisnis.news.viva.co.id/news/read/280960-banyakperusahaan-keluarga-tak-mau-terbuka, accessed on 20 January 2012.

66 This notion is also confirmed by Deputy Assistant of Control \& Accountability of Cooperatives \& Small-Medium Enterprises (SMEs), the Ministry of Cooperatives and Small and Medium Enterprises Republic of Indonesia.

${ }^{67}$ J. Tapies and J.L. Ward, eds., Family Values and Value Creation: How Do Family Owned Business Foster Enduring Value, (New York: Palgrave McMillan, 2008), pp. 71-101. 
partnership (CV) or limited liability company/corporation (PT).

Family businesses are a major driver in the Indonesian economy, playing an even larger role than previously thought, and perform as well as non-family business counterpart. However, most of the data regarding "family firms" in Indonesia would refer to one legal form of business organizations, namely PT. Consequently, it is difficult to find accurate data on family firms in other legal forms such as Firma or CV.

The policy initiatives regarding family business have to be developed. The need for some uniformity or at least a fair degree of consistency in defining family firm cannot be overemphasized. It is necessary to create a widely acceptable definition of "family firm" since it is important to the development of a more uniform body of law and policy directly impacting these family firms. The national government should consider adopting measures to create a more favorable environment for family business, for example in areas of taxation and company law. Policy measures must be enacted so as to ensure the survival of this business model regardless the legal form of the enterprises.

Indonesia, as a developing country with a profusion of family firms, should focus on taking advantage of the qualities that make family firms outperform non-family firms. At the same time, it should remove those features of entrenched family capitalism that can harm the national economy. It is because family firms have certain characteristics that can result in a competitive advantage compared to non-family business.

In order to support the growth of the family firms in Indonesia, the government might consider to taking certain policy agendas as follows: ${ }^{68}$

1. to provide legal definition of what family firm is. A definition proposed by European Expert Group on Family Business is worth to be taken into account. ${ }^{69} \mathrm{~A}$ commonly recognized definition of family firm will help raise the awareness of policy makers and general public of the importance of family firm.

2. to develop regulations mainly linked to facilitating the continuation of family firm, the mechanism allowing additional financing alternatives without risking the operational of the firm, and the planning of business transfer.

3. to register family firms as a separate group. This is necessary for providing accurate information about family firm.

4. to rearrange tax payment. Taxes should be paid if the company is sold to a third party, but they are not paid if it is only transferred to the next generation. For example, in the Netherlands, from 1 January 2007, there is exemption of $75 \%$ of taxes which have to be paid in the case of transfer of firms. ${ }^{70}$ According to PricewaterhouseCoopers Family Business Survey 2007/2008, almost 2/3 of respondents consider that simplification of the tax regime or reduction of the tax

\footnotetext{
${ }^{68}$ These policy agendas must be implemented to any legal form of business organizations or enterprises recognized in Indonesia.

${ }^{69}$ The proposed definition is that a firm, of any size, is a family firm, if (1). The majority of decisionmaking rights are in the possession of the natural person(s) who has/have established the firm, or in the possession of the natural person(s) who has/have acquired the share capital of the firm, or in the possession of their spouse, parent, child or children's direct heirs; (2). The majority of decision-making rights are indirect or direct; (3). At least one representative of the family or kin is formally involved in the governance of the firm; (4). For a listed company, if the person who has established or acquired the share capital or their families or descendants posses $25 \%$ of the decision-making rights mandated by their share capital. See: European Commission, op.cit, p. 4.
}

70 Thomassen, op.cit, p. 15. 
burden should be a top priority for governments over the next three to five years.

5. to educate more on family firms issues. It is important since there is little attention for family firms. This will avoid inaccurate assumptions such as associating all family business with SMEs. Both family firms and organizations representing the family firm sector should take an active role to raise awareness of the importance of the sector and to promote the development of a family firm institutional framework. .

The fact that family firms are more likely to play an active role in supporting local, national and international charities, encourages them to prepare themselves for the future. With the support of the government, they need and have to continue growing by establishing logical organizational and governance structures. This is the moment in which the governments should focus more on this unique type of firm, i.e., family firm.

\section{Bibliography}

\section{Legal documents}

Indonesia. Undang-Undang tentang Perseroan Terbatas (Law regarding Limited Liability Company). UU No. 40 tahun 2007, LN No. 106 tahun 2007 (Law Number 40 year 2007, SG No. 106 Year 2007).

Indonesia. Undang-undang tentang Usaha Mikro, Kecil, dan Menengah (Law regarding Micro, Small, Medium Enterprises). UU No. 20 tahun 2008, LN No. 93 tahun 2008 (Law No. 20 Year 2008, SG No. 93 year 2008).

Burgerlijke Wetboek (Indonesian Civil Code), Staatblad. 1847-23.

Wetboek van Koophandel voor Indonesie (Indonesian Commercial Code), Staatblad. 1847-23.

\section{Books}

Astrachan, Joseph H., Sabine B. Klein \& Kosmas X. Smyrnios.The F-PEC Scale of Family Influence: A Proposal for Solving the Family Business Definition Problem, Handbook of Research on Family Business. Edward Elgar: United Kingdom, 2006.

Bresnan, John, et.al.Indonesia: The Great Transition. Lanham, MD: Rowman \& Liitlefield Publishers, 2005.

Cadbury, Sir Adrian. Family Firms and their Governance: Creating Tomorrow's Company form Today's. Great Britain: Egon Zehnder International, 2000.

Ceja, Lucia \& Josep Tapies. “Corporate Values Guiding the World's Largerst FamilyOwned Business: A Comparison with Non-Family Firms." Working Paper-916, March 2011, IESE Business School, University of Navarra.

Colli, Andrea \& Mary Rose. "Family Business." In The Oxford Handbook of Business History. Edited by Geoffrey G. Jones and Jonathan Zeitlin. (Oxford: Oxford University Press, 2008).

Dieleman, Marleen. "How Chinese are Entrepreneurial Strategies of Ethnic Chinese Business Groups in Southeast Asia? A Multifaceted Analysis of the Salim Group of Indonesia. Netherlands: Leiden University Press, 2007.

Floren, Roberto, Lorranine Uhlaner and Martha Berent-Braun. "Family Business in the Netherlands, Characteristics and Success Factors: A Report for the Ministry of Economic Affairs." Center for Entrepreneurship, Nyenrode Business Universiteit, Breukelen, the Netherlands, 25 January 2010.

KMU Forschung Austria. "Overview of Family Business Relevant Issues." Final Report. KMU Forschung Austria: Vienna, 2008. 
Koopman, Martin \& Kevin Sebel. "The Internationalization of Family Firms: Facilitating and Contraining Features." Master Thesis, Jonkoping International Business School, 2009.

Morck, Randall K. \& Lloyd Steier. "The Global History of Corporate Governance: An Introduction."in A History of Corporate Governance Around the World, edited by Randall K. Morck (Chicago: University of Chicago Press 2005).

PricewaterhouseCoopers.Making a Difference, The PricewaterhouseCoopers Family Business Survey 2007/08. 2008.

Tapies, J. \& J.L. Ward,eds. Family Values and Value Creation: How Do Family Owned Business Foster Enduring Value. New York: Palgrave McMillan, 2008.

Ward, J.L. "Introduction." in Family values and values creation. The fostering of enduring values within family-owned businesses. Edited by J. L. Ward. (Hampshire, England: Palgrave Macmillan, 2008).

\section{Articles}

Anderson \& Reeb. "Founding-Family Ownership and Firm Performance." The Journal of Finance 58 (2003): 1301-1328.

Benedict, Burton. "Family Firms and Economic Development." Southwestern Journal of Anthropology 24, no. 1 (1968): 1-19.

Burkart, Mike Fausto Panunzi \& Andrei Schleifer. "Family Firms."58 The Journal of Finance No. 5 (2003): 2167-2202.

Chua, Jess H., James J. Chrisman \& Erick P.C.Chang, Are Family Firms Born \& Made? An Exploratory Investigation, Family Business Review 17 (March, 2004): 37-54.

Church, Roy. "The Family Firm in Industrial Capitalism: International Perspectives on Hypotheses and History." Business History 35(1993): 17-43.

Claessens, Stijn Simeon Djankov \& Larry H.P.Lang. "The Separation of Ownership and Control in East Asia Corporations." Journal of Financial Economics 58 (2000): 81-112.

Faccio, M.\& Lang."The Ultimate Ownership of Western European Corporations.”Journal of Financial Economics 65 (2002): 365-395.

Lee, S. Lim and W.S. Lim. "Family Business Succession: Appropriation Risk and Choice of Successor." Academy of Management Review 28,no. 4, (2003): 657-666.

Lefort, Fernando. "Ownership Structure and Market Valuation of Family Groups in Chile." Corporate Ownership \& Control 3, no. 2 (2005-2006): 90-105.

Littunen, H. \& K. Hyrsky. "The Early Entrepreneurial Stage in Finnish Family and Non Family Firms." Family Business Review13, no. 1 (2000): 42-45.

Miller, et. al. "Are Family Firms Really Superior Performers?" Journal of Corporate Finance 13 (2007): 829-858

Poza, E.J. \& T. Messer. "Spousal Leadership and Continuity in the Family Firm." Family Business Review, 14no. 1 (2001): 25-36.

Schulze, William S \& Eric Gedajlovic."Whither Family Business.” Journal of Management Studies 47 (2010): 191-204.

Suehiro, Akira. "Family Business Reassessed: Corporate Structure and Late-starting Industrialization in Thailand." The developing Economies 31, issue 4(1993): 378-407.

Weidenbaum, Murray. "The Chinese Family Business Enterprise." California Management Review 38, no. 4 (1996): 141-156. 


\section{Websites}

European Commission. "Final Report of the Expert Group on Overview of FamilyBusiness-Relevant Issues: Research, Networks, Policy Measures, and Existing Studies." Enterprise and Industry Directorate-General. at http://ec.europa. eu/enterprise/policies/sme/promoting-enterpreneurship/family-business. accessed on 27 March 2013.

Floren, R.H. "Facts and Figures of the Family Business: 10 years of research on family business." BDO Accountants \& Adviseurs, accessed at www.nyenrode.nl, January 10, 2013.

Forbes. "Indonesia's 50 richest." http://www.forbes.com/indonesia-billionaires. accessed on 15 February 2013.

Susanto, AB. "Menguak Perusahaan Keluarga di Indonesia." ["Revealing Family Firms in Indonesia"]. http://www.jakartaconsulting.com/art-0507.htm, accessed on 26 March 2013.

SWA. “Ketika Perusahaan Keluarga Berhadapan 'Seven-plus-Seven'” [“When Family Companies facing 'Seven-plus-seven'”] http://swa.co.id/business-strategy/ ketika-perusahaan-keluarga-berhadapan-seven-plus-seven. accessed on March 2013.

The President Post. "Leadership in Family Business." http://www.thepresidentpost. com/?p=15411. accessed on February 2013. 